\title{
Platon und Aristoteles in der Kosmologie des Proklos
}

Ein Kommentar zu den 18 Argumenten für die Ewigkeit der Welt bei Johannes Philoponos

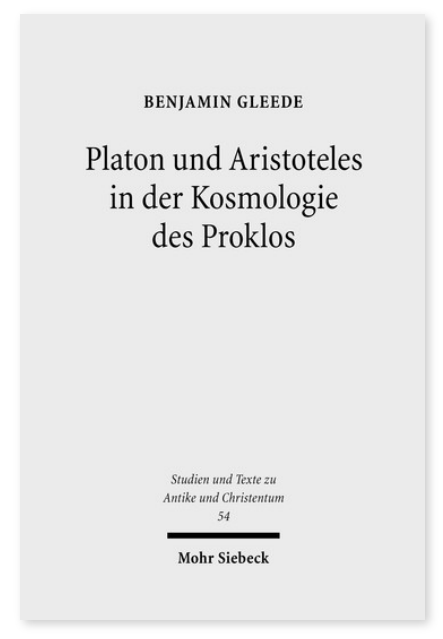

2009. XIV, 546 Seiten. STAC 54

ISBN 978-3-16-151353-4

DOI 10.1628/978-3-16-151353-4

eBook PDF 104,00€

ISBN 978-3-16-150043-5

fadengeheftete Broschur 104,00€
Anders als ihre Übermittlung in einem als christliche Apologetik präsentierten Traktat suggeriert, bieten die 18 Argumente des Proklos für die Ewigkeit der Welt insgesamt keine Polemik gegen die christliche Schöpfungslehre, sondern dokumentieren vielmehr in exemplarischer Weise die für den Neuplatonismus charakteristischen intensiven exegetischen Bemühungen um das Verhältnis von Platon und Aristoteles. Dabei zeigt sich, in welch überraschend hohem Maße der spätere Platonismus darum bemüht war, die sachlichen Einsichten des Aristoteles nicht nur in sein eigenes System zu integrieren, sondern auch als dem Gehalt nach platonisch und damit Aristoteles selbst als den herausragendsten Schüler Platons darzustellen. Aller Gewaltsamkeit in der Einzelinterpretation zum Trotz beweisen Platons Erben in der Akademie dabei eine bewundernswerte Intuition für die Verwandtschaft platonischer und aristotelischer Naturbetrachtung, von der auch die moderne philosophiehistorische Forschung noch lernen kann.

Benjamin Gleede ist Wissenschaftlicher Mitarbeiter (SNF Projekt) am Lehrstuhl für Kirchen und Theologiegeschichte an der Theologischen Fakultät der Universität Zürich.

Jetzt bestellen:

https://mohrsiebeck.com/buch/platon-und-aristoteles-in-der-kosmologie-des-proklos-9783161513534?no_cache=1 order@mohrsiebeck.com

Telefon: +49 (0)7071-923-17

Telefax: +49(0)7071-51104 